\title{
Uncertainty Communication Status: Theory or Science
}

\author{
Ștefan Vlăduțescu \\ University of Craiova, A. I. Cuza, no. 13, Craiova, Romania \\ E-mail address: stefan.vladutescu@yahoo.com
}

\begin{abstract}
In this study, we argue in favor of the thesis that communication ar an a lic disc line faces many uncertainties. One of these is the uncertainty regarding the status. $\mathrm{me}$ talk $\mathrm{k}$. theory, others about the Communication Science, about Communice "Sciences information et de la Communication" (SIC), Communication studies etc. Nue ar qu ion about the status of the communication is: the study of communication is a theory or a ence, is a $\mathrm{k}$ cogitative system or a strong cogitative system? We distinguish five causes that d ermined commun ation study to remain to this day a weak cogitative system: the effervescence of the heoretical-scientific and practical researches in a knowledge area full of promises; heavy coagulation a cogitation 1 communication community; refusal of the rule; articulation of communicational think is "weal thinking" - "weak thought" G. Vattimo); and the delay in the development o the commu. ontology. Discipline that studies communication is a weak-cogitative thinking sys $\mathrm{m}^{\mathrm{m}} \mathrm{m}$ of theories but not yet a science. As a set of weak theories, the study of communication is bo om 1 ce. In any case, discipline that studies communication is on the way to become-a science.
\end{abstract}

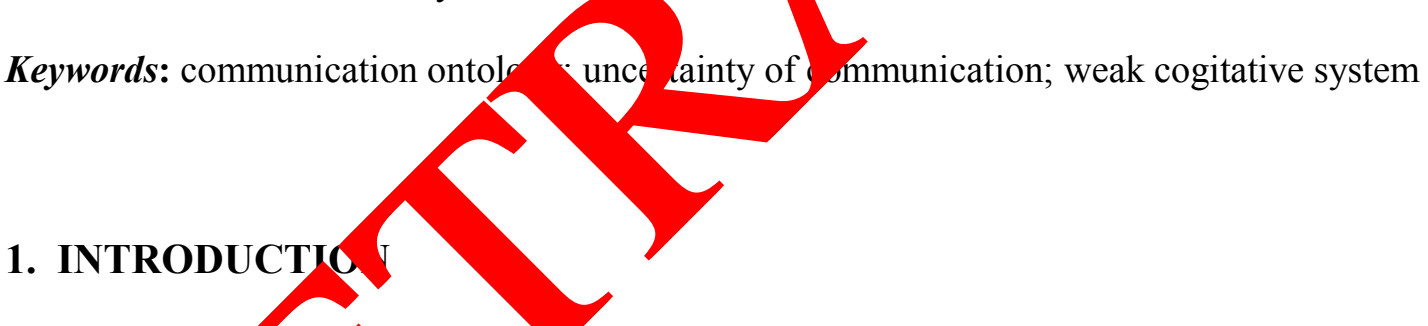

There e sign icant relational gains which will lead to a scientific community of communicatio would ommunicate well (De la Peza Casares, 2013).

A theory comm anication can be based on interpretation, but a science must be objer ave, thodic stematically and should allow for verification. L. Duarte and B. Alonso al heak thout this, they see the future of communication sciences as "based on objectivity, truth, emrpmud verification as the only method of approaching reality" (Duarte L., Alonso G., 2008,

Howy,er, at present there is a controversy regarding the status of communication, that status is uncertain (see Kulczycki, 2008; Wedland, 2013).

\section{FIVE CAUSES}

(A) The first cause of communication as discipline without accredited title and object is the effervescence of the theoretical-scientific and applicative researches in a knowledge area full of promises. The fourth and the fifth decades of the $20^{\text {th }}$ Century were the beginning of the 
world of true communication. The coherent thinking and discourse about communication began then (Berger \& Calabrese, 1975; Berger \& Gudykunst, 1991; Ritt, 2003; Balaban, 2008). A hesitant logos was established during those years, but it was determined by communication. "Logos" means "thinking, study", but also "speech", in Greek. We would say that a thought out discourse about communication was established between 1940 and 1960. As Uma Narula states, "research in Communication has conceptualized communication per se in 1940s and 1950s, and to develop Model and Theories" (Narula U., 2006, p. 1). The discourse in those years was thought out, but it was a discourse on several voices. It is an apparently divergent discourse. In essence, it was a matter of a thought out discourse and converging, in a fundamental lima and yet a hesitant discourse, of a beginning of the world. For those analyzing the ovolutu of "communication" today, they will note that it hesitated to be defined as science set an obj and include it into a "-logy" ("logos"), such as: psychology, anthropology, sncion etc.

(B) We may identify the second cause in the slow coagula on o a cos ti nal communication community. "Communication" specialists making stul at of he object called communication originating from a field such as psych sy, iology rechnical communications. The lack of some schools and a "communicati" commun ha, delayed the paradigmatic imposition of a new discipline. Alternati ely, mething ase happened: communicational thinking centers from various continen tund a v in being isolated, as well as in not communicating among themselves. St phen W. Littlej 1 and Karen A. Foss noted the allure of divergence of the particularity $v$ ere the American, European and Asian communication schools were established: "Th developm nt of the discipline of communication took different forms and foci in diffo parts the world. Communication theory has had a different history in Europe Asia, an un strica than in the United States" (Littlejohn S. W., \& Foss K. A., 2008, p. 5).

(C) A third cause is the rejection of rule 1940, 1950 meant the beginning of postmodernism. Concordantly, it was matter a out freeing the world from the war pressures and constraints it involved. A at ap etite for eedom represented the social background of the time. As a form of fre m, found its favorable ground. The freedom to speak and think in term of a new cipline was however smiting a more influential, more powerful freedom. Po stm rnism wa in inhibiting freedom for communication. Freedom is decoded, under its rical tras as freedom from rules. As James Richard Mensch showed, "the postmoder "sm period (...) Sost-normative", it is a matter of "a post-normative view of self and rea " " (M sch J. R., 2004, p. 1 and p. 283). Postmodernist "post-normative" propensity dia ame as e communication specialists to no longer incline easily before the scientifi le to $\mathrm{rch} f \mathrm{r}$ the basis, for the integration in knowing the problem worldwide, and $o$ sea for a cy nus on this basis. Fleeing from norms puts into motion the beginnings of tisc line called "communication".

unimcation of the communication "theories" has been attempted several times. It is an unatta ble objective. The theories as theories cannot be unified. First of all, because theories are unilateral cogitative constructs, they address just the ontological characteristic of the field (Craig, 2013; also Pavalache-Ilie \& Unianu, 2012; Pavalache-Ilie, 2012). Theories arise from perspectives which consensus cannot exist for. Theories could find their convergence in a strong cogitative system, in a strong science, in a strong General Communication Science. To unify the theories is not actually one of the ideals of the theories themselves. It is an illusory aspiration. This convergence ideal could be done only inside a comprehensive science, settled in object and methods. The unification could occur based on a strong ontology, under the conditions of a clear epistemology and a consistent methodology. It is known that several 
theories individually explaining the ontological, specific elements subsist in a science. We emphasize: theories can be unified in a science.

(D) Fourth of all, postmodernism comes with a "weak thinking". A weak thinking can only cause a weak cogitative system. A paradigmatic science is a strong cogitative compact system. Delia Cristina Balaban considers that the discipline that is concerned with communication is a science; in the study "Development of Communication Science in Romania. Challenges and Perspecives. Professional Communication and Translation Studies, 6(1-2), 3-10" asserts that "Communication Science is a relatively new science" (Balaban, 2013, p. 3). Left free, postmodernism will be driven by originality, pluralism, diversity an ed freedom of thinking, insight, a mix of ideas, categories and concepts. Its weak thi king can cause theories. Postmodernism cannot generate science; the maximum of its tative for can only rise to the level of a theory. Postmodernism produces fascinng, doxic /, enlightening theories, but it causes theories again and again. By itself, it produ es jus which is salutary and worth being promoted. However, the conce or anza on of the cognitive and computational experiences is only established as a p ign the con ef the cogitative compact science system. Weak thinking must be b ght in the ny rgence of a critical thinking in the area of the same thinking that $t^{\prime}$ nks the selt while thinking (Bârgăoanu, Negrea \& Dascălu, 2010). When Jacques tha wà ractically showing the operation of a weak ontology, Gianni Vattimo establis ced weak thinkin Vattimo showed that "weak thought" is based on Martin Heidegger' concept "Verwindung", which means "declination/distortion" (Vattimo G., 2012, p. 46). D ination det rmines that "One has access to Being not through presence but only through reco tion, fo. Being cannot be defined as that which is but only as that which is passe "(Vattim , 2012, p. 47) (also Bușu \& Bușu, 2014). No longer staying determined in prese ce, astmodernist cogitative subject sees the world through the lens of a thinking that lets $t$ n pass $y$. Abdicating from seeing the present as present, the reality of the presen oticed s bsequently as a delay, as past, as belonging to the past. Abandoning the pres ce is $\delta$ aband the "strong thought, that of deductive coagency", the "strong catego ies Carravetta clarifies sever. thrngs, percelving "weak thinking" as "dissolution of strong thought" and stating th stead of "ms, principles, strong theories", the weak thinking brings "interpretatio " (C. vetta P.)2012, p. 11 and p. 4) (also Wendland M., 2013).

(E) The fi $r$ cause is the $y$ in the development of the communication ontology. Weak thinking dep "es ont gysigniricantly because, above all, it does not see well and directly the existence and cences. Veak thinking shapes a compliance schedule, where a "weak ontolog "-esults m: " he program of weak ontology holds that such change in the way of thin ang a the fo amental traits (even simply descriptively, or typical) of Being will have incp ant anceamences" (Vattimo G., 2012, p. 47). A weak ontology is an ontology that does not sed गा the meld which it is responsible for. It is that which is on the verge of losing it after seeing it. thout an ontology settled in its own responsibilities, a theory or a weaken science. Already imposed or in the process of consolidation, theories-sciences likely to have "weak ontology" will be unable to theorize, categorize, conceptualize, in order to be fully acceptable. As Peter Carravetta notes, "weak thought can show the way to a contemporary understanding of hemeneutics, theories of knowledge, ethics, and discourse" (Carravetta P., 2012, p. 2) (also Babrow, 2001; Mucundorfeanu \& Abrudan, 2009; Radu, 2012; Borowski (a), 2013).

Of course, no ontology is perfect. All indexes of categories and concepts have questionable parts, and some ontological models are contradictory. All ontologies are imperfect. Most of them have specific problems that are solved by applicative or technical- 
scientific research. The weak ontology of communication has however structuring difficulties: the patterns are common and divergent, the theories are many and unclear, some concepts are not thoroughly grounded, the network of categories is not articulated in a coherent whole within one science. Out of these, theories are the weakest and most toxic part. The multitude of theories is what undermines the consolidation of a unitary understanding of the communication process, of the basic ontological elements. This is why in 70 years a theory or a communication science difficultly, troublesomely and ambiguously creates a tradition (Dâncu, 1999; Barr, 2001; Koester \& Lustig, 2012; Knight, 2012).

In 70 years of development, communication itself defined many traditions. Stenhan W. Littlejohn and Karen A. Foss, together with Robert T. Craig ( The "Traditions" Ma AX-Stan d - R. T. Craig) accredited the idea that it would be a matter of 7 traditions: " ig describ seven traditional standpoints that provide different ways of talking about crmm ation: the rhetorical; (2) the semiotic; (3) the phenomenological; (4) the cyb netic; (5) so 0 psychological; (6) the socio-cultural; and (7) the critical" (Littlejohn C W., F K A. 2008, p. 7). When dealing with the matter, the two renowned specialists al the 7 tr litions in the following order: "The Semiotic tradition", "The Phenop nologica Tradi on", "The Cybernetic Tradition", "The Socio-psychological Tradition" Socio-cu al Tradition", "The Critical Tradition" and "The Rhetorical Tradition" (Ji ejohn W., Foss K.A., 2008, pp. 35-55) (also Stoica, 2007; Crețu, 2009).

At the level of axis 1 (the ontological axis), ther have been registe ed effects that clarified that we currently have a "weak ontology" in commu vation. A higher level effect of the "weak thought" is, as Peter Carravetta says, that "most fo of theo zing cannot find a credible legitimization" (Carravetta P., 2012, p. 2) The mum communication theories and traditions is explained through the lack of " legitimacy" on behalf of each individual (Radu, 2012; Abrudan, 2013; Borowski (b), 2 13)

A paradox of the communication discil "ne (or the "communication science", of the "communication theory", of the col unicati n studies", of the "communicology") is that there was no-one to give legi zatio to some heories that could have been legitimated. In other words, the institu alis not produced, not because the theories of communication would t have valuable and appeared as not having "credible legitimacy", but bec asc re was h one anymore to give them legitimacy. And, more specifically, in wy the specialists had no more time to give legitimacy to others' theories (Fârte 2004: Grant, 20 Maior, 2009; Cobley \& Schulz, 2013). Strangely, the history of the comp icatio ides shows that communication specialists do not communicate well towards comm ation. 7 ey do not communicate well with each other. From a cluster of credita theo ut without many specialists to credit them, strong the $\mathrm{y} / \mathrm{scic} \mathrm{ee} / \mathrm{comn}$ Mication studies or a communicology could not be created and cannot be crea to su prisingly, we have many specialists in a given field, but the community of scient in a frerd lacks the shaping influence. The scientific paradigm is established by the communt 8 specialists (Rus, 2004; Berger, Roloff \& Roskos-Ewoldsen, 2010; Balaban \& Abrudan, 2011).

\section{CONCLUSION}

Not being based on a strong thinking, communication remains an amorphous construction as a discipline. By looking from afar, the impression is that communication specialists theorize excessively. Following a thorough analysis, the first impression is however confirmed: in the 
universe of communication, theorization is done excessively. Weak thinking, based mainly on interpretation, theorization, is descriptive and typical, too mobilized in the inscription of types and models. The scientific and institutional destiny of communication has been seriously affected by weak thinking. Status of communication changes radically: the study of communication is on the way to become a science.

\section{ACKNOWLEDGEMENT}

The study is developed under the research grant of internal competition for grants from the University of Craiova - Romania.

\section{References}

[1] Abrudan M. C., Journal for the Study of Religions and Ideologie 237-250.

[2] Babrow A. S., Journal of Communication 51(3) (2001) 55573.

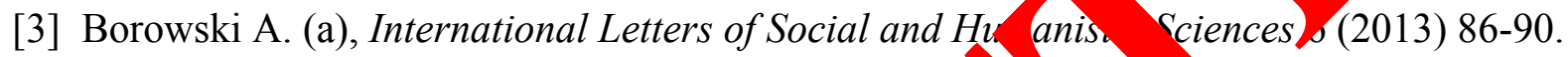

[4] Balaban, Delia Cristina; Abrudan, Mirela Codruța reveșa Transı ya de Științe ale
Comunicării 2(13) (2011) 3-8.

[5] Balaban, Delia Cristina (2013). Development of mmunicat on Science in Romania Challenges and Perspecives. Professional Comm ation Ad Translation Studies.

[6] Barr D. J. (2001). Trouble in mind: Pard andic indices of effort and uncertainty in communication. In C. Cavé, I. Guäitella, Sz atr.), Oralité et gestualité:

Interactions et comportements multimodat dans la communication, 597-600.

[7] Berger C. R., Calabrese R. Hun n Comm Mication Research 1 (1975) 99-112.

[8] Berger C. R., Gudykun W. certainty and communication. In B. Dervin \& M. Voight (Eds.), P gress in c nunication sciences (pp. 21-66). Vol. 10. Norwood, NJ: Ablex.

[9] Berger C. R. Joff M. L oskos-Ewoldsen D. (2010). What is Communication Science? I C. R Berger, M E. Roloff \& D. Roskos-Ewoldsen (Eds.), The Handbook of Commy tion ocen 1 e (pp. 3-20). (2 ${ }^{\text {nd }}$ ed.). Thousand Oaks, CA: Sage.

[10] Bormski a ), Int rnational Letters of Social and Humanistic Sciences 4 (2013)

[1] 1 ha, Negrea Elena, Dascălu Roxana (2010). Communicating the European

[12] Buşu Kea-Valentin, Buşu Oana-Cristina, International Letters of Social and Humanistic Sciences 9 (2014) 100-107.

[13] Carravetta P. (2012). What Is ,,Weak Thought”? The Original Theses and context of il pensiero debole. In G. Vattimo \& A. Rovatti (Eds.), Weak Thought. New York Press.

[14] Cobley P., Schulz P. J. (2013). Introduction. In P. Cobley \& P. J. Schulz (Eds.), Theories and Models of Communication (pp. 1-16). (Vol. 1). Walter de Gruyter.

[15] Craig R. T. (2013). Constructing theories in communication research. In P. Cobley \& P. J. Schulz (Eds.), Theories and Models of Communication (pp.39-57). Walter de Gruyter. 
[16] Crețu Ioana-Narcisa, Introducere în ştiințele comunicării. Note de curs, Editura Universității Lucian Blaga din Sibiu, 2009.

[17] Dâncu V. S. (1999). Comunicarea simbolică. Arhitectura discursului publicitar. Dacia, Cluj-Napoca.

[18] De la Peza Casares, M. (2013). Los estudios de comunicación: disciplina o indisciplina. Comunicación y sociedad, (20), 11-32.

[19] Tittenbrun J., International Letters of Social and Humanistic Sciences 2 (2014) 20-40.

[20] Duarte L., Alonso G. (2008). Perspective for Development of Theories of Communication in Latin America. Paper presented at The Annual Meetin of the International Communication Association, Marriott Hotel, San Diego, 200 http://www.allacademic.com/meta/p111743_index.html.

[21] Fârte G. I. (2004). Comunicarea. O abordare praxiologică. Iaşi litura

[22] Goldsmith D. J., Journal of Communication 51(3) (2001) 51 ras.

[23] Grant C. B. (2007). Uncertainty and communication: $N$ w retical in stigations. Palgrave Macmillan.

[24] Knight F. H. (2012). Risk, uncertainty and profit DoverPublicaty s.com.

[25] Koester J., Lustig M. (2012). Intercultural com etence: Interpersonal communication across cultures. Pearson Prentice Hall.

[26] Kulczycki E. (2008). Status komuniko ij-przyc_ do dyskusji. Poznań.

[27] Littlejohn S. W., Foss K. A. (2008). The ries on communication. (9 $9^{\text {th }}$ ed.). Belmont, CA, Thompson Wadsworth.

[28] Maior George Cristian (20 9). In rtitudin Gândire strategică şi relaţii internaţionale in secolul XXI. Bucuresir. itur Don

[29] Mensch J. R. (2004 Knowing d Being. Penn State Press.

[30] Mucundorfeany M., udan M., ournal of Media Research-Revista de Studii Media 5 (2009) 89 o.

[31] Narula V , (200, Commu ication Models. New Delhi: Atlantic.

[32] Pavalach M. (20 2). Deprinderi de comunicare. Internet source.

[33] Aim ă Ma raistaru Aurelia (2013). Self-Directed Learning in Economic Educ lion.

[34] M.; Unianu, E. M., Procedia-Social and Behavioral Sciences 33 (2012) 19. 02.

[35] Radu -ristian, Journal of Media Research-Revista de Studii Media, 1 (12) (2012) 15-26.

[36] Wendland, Michał, Dialogue and Universalism 1 (2013) 51-63.

[37] Radu Cristian, Journal for the Study of Religions and Ideologies 31 (2012) 206-222.

[38] Ritt A. (2003). Comunicarea organizaţională externă. Timişoara: Editura Mirton.

[39] Rus F. C. (2004). Relaţii publice şi publicitate. Iaşi, Institutul European.

[40] Stoica D. S., Revista Transilvană de Ştiinţe ale Comunicării 5 (2007) 60-64. 
[41] Vattimo G. (2012). Dialectics, Difference, Weak Thought. In G. Vattimo \& A. Rovatti (Eds.), Weak Thought. New York Press.

[42] Borowski A. (c), International Letters of Social and Humanistic Sciences 7 (2013) 113-118.

[43] Bârgăoanu Alina, Negrea Elena, Dascălu Roxana (2010). The Emergence of a European Public Sphere. An analysis of Europe's News Website presseurop. eu.

[44] Iorgulescu Alexandra, International Letters of Social and Humanistic Sciences 7 (2014) 14-21.

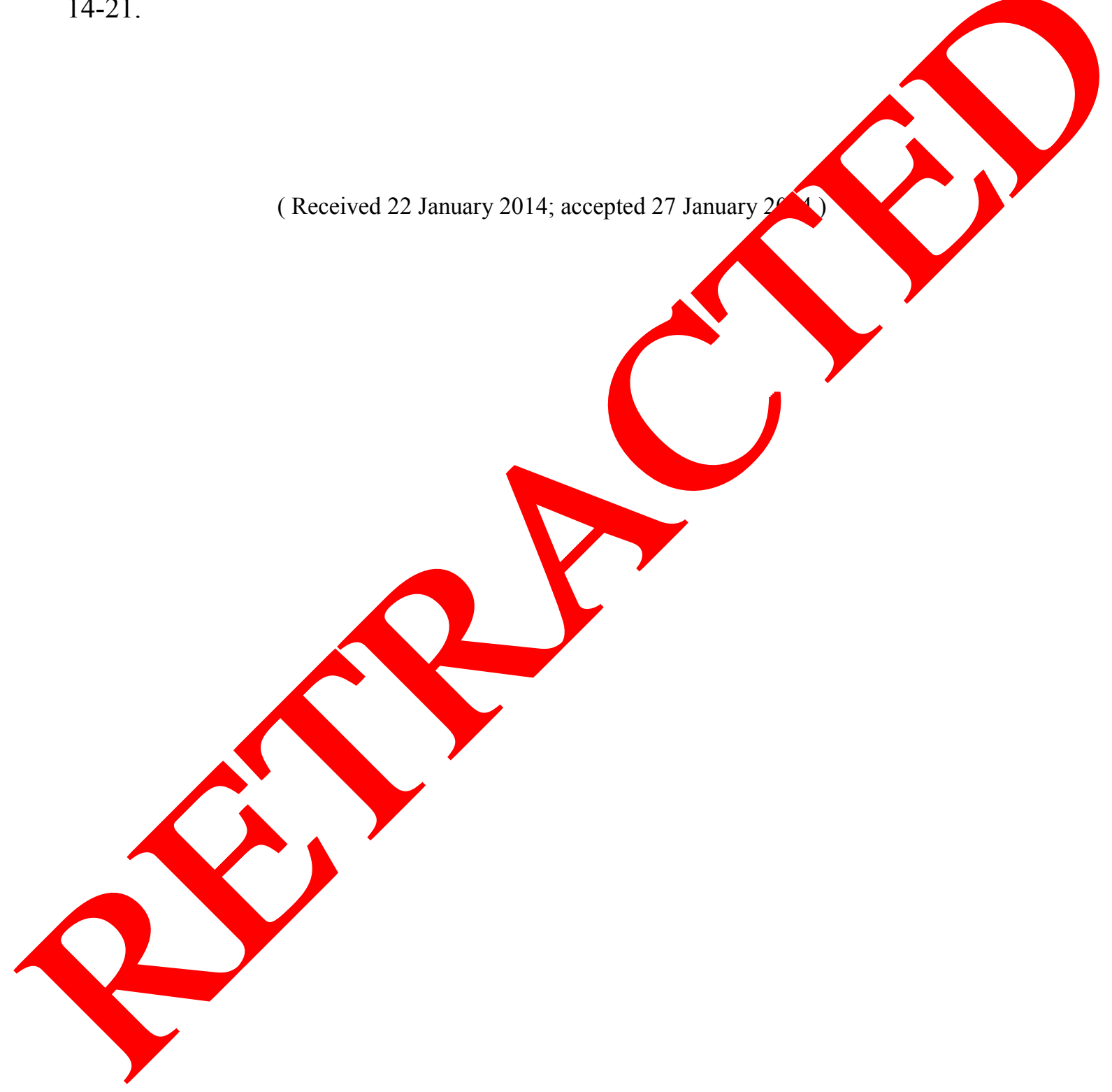

